\title{
Cloud Computing and Student's Record Management Efficiency in Niger Delta University
}

\author{
Amakiri Don-Solomon and Michael Joshua Ayawei
}

\begin{abstract}
Information is relatively the life conduit of any organization. An inappropriate management of records and the information contained therein could cost organization both operational and financial fortune. The focus of this paper was to establish the empirical link between cloud computing and student's record management efficiency in Niger Delta University. Software as a service (Saas) and Platform as a service (Paas) were used to operationalize the predictor variable, while records accessibility and safety were used as measures of record management efficiency. 301 staffers were sampled randomly with questionnaire. Data collected was inferential analyzed using spearman rank order correlation coefficient with the aid of SPSS. Result shows high correlation amongst all variables which means that increase cloud computing practices in the institution would enhance record's management efficiency. The study recommends therefore that management of Niger Delta University should leverage on available software service provides to store all students' records on cloud to avoid losses of records due to flood and undue physical environmental conditions. Also, cloud computing model should be utilized for efficiency in record management to create good public image for vantage competitive edge.
\end{abstract}

Index Terms - Cloud computing; Records management; accessibility; records safety, PaaS, SaaS.

\section{INTRODUCTION}

Efficient records management is integral to organizational functionality and success especially in this information age where there is an upsurge of information need to inform sound strategic decision making in organizations. To measure up with prevailing competition in a dynamic business environment, organizations must be deliberate in its attempt to adopt more flexible information or records management practices. Cloud computing is one of such flexibly available records management tools contemporary organizations utilizes to remain competitive.

Pinal [1] describes cloud computing as a computing model, that harness pool of systems publicly and privately linked together to share dynamically scalable infrastructure, manage data and file storage. Obviously, with the aid of internet, records stored in cloud can be accessed and managed anywhere through available devices [2].

As a result of observed abnormalities in records management system in the educational sector especially in the institution under study, Bibi, Katsaros and Bozanis [3] raised the concern of the dilemma facing Niger Delta University whether to house organizational information

Published on September 10, 2020.

A. Don-Solomon, Niger Delta University, Nigeria.

(corresponding e-mail: donamaco52@gmail.com) (records) on premise or on cloud with the realities of incidences of loss of students records due to poor on premises record management system adopted by the institution which has resulted to graduates from this school faced with the difficulty of pursuing advance degrees due to inability of the school to provide academic transcripts. The recurrent call for students to submit academic records from the faculty put to question the efficiency of its records management practice of the school although this may have been caused by the flood natural occurrence in the school and relocation of faculties to permanent site, but what measures have been put in place to guide against the incidence of records loss in the school? This is the motivation of the study. It is against this background the researchers seek to examine the efficacy of cloud computing as mechanism for efficient student's record management practice in Niger Delta University.

\section{A. Conceptual Frameworks}

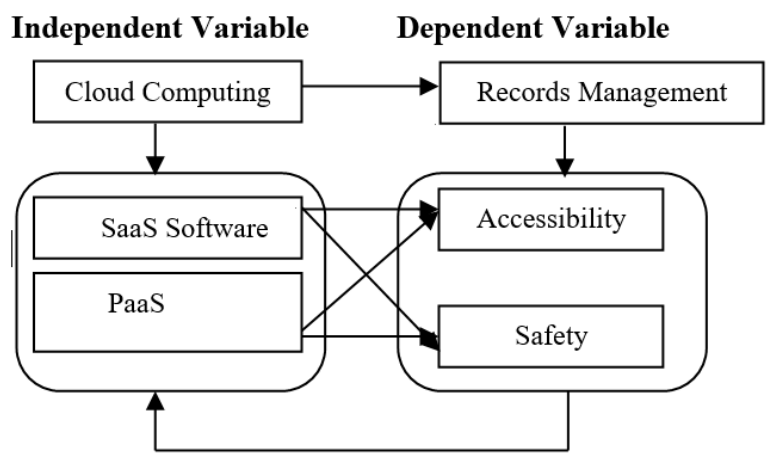

Fig. 1. Conceptualized by the researcher.

\section{B. Purpose of the Study}

The purpose of this research was to investigate the relationship between cloud computing and student records management efficiency in Niger Delta University. Specific objectives include:

1. To ascertain the relationship between Software as a service (SaaS) and records management.

2. To examine the extent Platform as a service (PaaS) is related to records management.

\section{Research Questions}

The following research questions guided the study:

1. What is the significant relationship between Software as a service (SaaS) and records accessibility?

2. What is the significant relationship between Software as a service (SaaS) and records safety?

M. J. Ayawei, Niger Delta University, Nigeria.

(e-mail: ayaweim ${ }^{\circledR}$ yahoo.co.uk) 
3. What is the significant relationship between Platform as a service (PaaS) and records accessibility?

4. What is the significant relationship between Platform as a service (PaaS) and records safety?

\section{Research Hypotheses}

In view of the above research questions, the null hypotheses are formulated for the study.

Ho1 There is no significant relationship between Software as a service (SaaS) and records accessibility.

$\mathrm{Ho}_{2}$ Software as a service (SaaS) has no significant relationship with records safety.

Hoz There is no significant relationship between Platform as a service (PaaS) and accessibility of records.

Ho4 Platform as a service (PaaS) is not significantly related to records safety.

\section{CONCEPTUAl REVIEW OF RElated Literatures}

\section{A. Cloud Computing}

Buyya, Yeo, Venugopal, Broberg, and Brandic [4] described cloud computing essentiality as the fifth convenience next to water, electricity, gas, and telephone which has made computing service prevalent in today's society. This was envisaged in 1961 by John McCarthy that cloud computing would be a "public utility" [5]. Mell and Timothy [6] asserts that National Institute of Standards and Technology (NIST) underpinned five cloud computing models with essential characteristics. On demand selfservice, resource pooling, rapid elasticity, Software as a service and platform as a service. These five models form the cloud computing landscape as it provides pool of information accessible at ease through service providers hence the latter two adopted as the dimensions of cloud computing - the predictor variable.

\section{B. Records Management}

Records management entails the management of records all through its lifecycle of creating, classifying, storing, maintaining, usage and eventual obliteration according to legal requirement for retention of such document. Langemo [7] shares similar thought positing record management as professional management of information in the physical form, the time records are received, pass through processing, distribution and placement in a storage and retrieval system until either eventual elimination or identification for permanent retention in archives.

A good judge of an efficient record management system is the ease of accessibility, safety, and retention, which forms the measures of the criterion variable in the current study.

Organizations invest so much to create, retain, and preserve records so as to be used for future referencing to inform sound decision making. If a user cannot locate a document at ease and on time, invariably the purpose of records keeping is defeated. As such, an efficient records management program should have in place manual or automated systems that can trace and retrieve records in a reliable and timely manner to meet its users.

According to the United Nations Archives and Records Management Section physical, environmental, and technological hazard can put records and information at risk.
Especially when records are misplaced or the information in them is compromised; the office or organization struggle to fulfill its mandates and further exposed to several significant operational and financial risks.

\section{MethodOLOGY}

Descriptive survey research design was adopted in an attempt to empirically ascertain about cloud computing and students record management efficiency in Niger Delta University. Data was collated primarily using questionnaire amongst four hundred and two (402) staffers of the institution that has direct responsibility of recording keeping randomly however, only 301 of the instruments are useful. Instrument for data collection was face validated by experts and subjected to test-retest technique which obtained a correlation of 0.86 reliability, above the 0.60 benchmark espoused by [8].

Spearman Rank Order Correlation coefficient was use as the statistical instrument used to analyze the hypothesis.

$$
r 2=1 \frac{6 \sum d 2}{N(d 2-1)}
$$

where

Spearman rank correlation coefficient.

$1=$ Unity i.e perfect correlation from which any value in the quality maybe taken to reduce the coefficient.

$6=$ this the constant value.

$\sum \mathrm{d} 2=$ the sum of the difference in the rank squared.

$\mathrm{N}=$ Number of cases.

\section{RESULT}

TABLE 1: DEMOGRAPHIC DISTRIBUTION OF RESPONDENTS

\begin{tabular}{|l|c|c|}
\hline Socio-Demographic & Frequency & Percentages (\%) \\
\hline Gender & & \\
\hline Male & 199 & 66 \\
\hline Female & 102 & 34 \\
\hline Total & $\mathbf{3 0 1}$ & $\mathbf{1 0 0}$ \\
\hline Age & & \\
\hline $1-5$ & 63 & 20.9 \\
\hline $6-10$ years & 89 & 29.6 \\
\hline $11-15$ & 100 & 33.2 \\
\hline above 15 years & 49 & 16.3 \\
\hline Total & $\mathbf{3 0 1}$ & 100 \\
\hline Education Qualification & & \\
\hline SSCE & 100 & 33.1 \\
\hline HND/BSc & 62 & 20.6 \\
\hline MSC/MBA & 99 & 33 \\
\hline Others & 40 & 13.3 \\
\hline Total & $\mathbf{3 0 1}$ & $\mathbf{1 0 0}$ \\
\hline Work Experience & & \\
\hline 1-5 years & $\mathbf{9 9}$ & $\mathbf{3 3}$ \\
\hline 6-10 years & $\mathbf{1 0 0}$ & $\mathbf{3 3 . 1}$ \\
\hline $\mathbf{1 1}$-above years & $\mathbf{1 0 2}$ & $\mathbf{3 4 . 9}$ \\
\hline & $\mathbf{3 0 1}$ & $\mathbf{1 0 0}$ \\
\hline
\end{tabular}

Table 1 shows that of the 301 respondents who responded to the questionnaires, as much as 199 respondents representing $66 \%$ of the population are male while only 102 $(34 \%)$ are females. Also, as much as 63 respondent (20.9\%) reported having a working experience spanning between 1- 5 years, $89(29.6 \%)$ have work experience spanning between 6 - 10 years, $100(33.2 \%)$ reported having work experience of 11 - 15 years, while only 49 (16.3) are reported having above 15 years. Finally, the majority of respondents $199(66.1 \%)$ 
are holders of MSC/MBA, $62(20.6 \%)$ are holders of HND/BSc certificate, $40(13.3 \%)$ are others. None of the respondents were observed working with a base qualification of SSCE.

\section{A. Test of Hypotheses}

This section deals essentially with statistical testing of the hypotheses formulated for this study and also interpreting the result making use of Spearman Rank Order Correlation Coefficient.

$\mathrm{H}_{\mathrm{o} 1}$ : There is no significant relationship between SaaS and Records Accessibility.

\begin{tabular}{|l|l|l|c|c|}
\hline \multicolumn{2}{|c|}{} & $\begin{array}{c}\text { Software as } \\
\text { service (SaaS) }\end{array}$ & $\begin{array}{c}\text { Records } \\
\text { Accessibi } \\
\text { lity }\end{array}$ \\
\hline \multirow{4}{*}{$\begin{array}{l}\text { Spearman's } \\
\text { rho }\end{array}$} & $\begin{array}{l}\text { Software as } \\
\text { Service (SaaS) } \\
\text { and }\end{array}$ & $\begin{array}{l}\text { Correlation } \\
\text { Coefficient }\end{array}$ & 1.000 & $.837^{* *}$ \\
\cline { 2 - 5 } & Sig. (2-tailed) &. & .000 \\
\cline { 2 - 5 } & $\begin{array}{l}\text { N } \\
\text { Records } \\
\text { Accessibility }\end{array}$ & $\begin{array}{l}\text { Correlation } \\
\text { Coefficient }\end{array}$ & $.837^{* *}$ & 1.000 \\
\cline { 3 - 5 } & Sig. (2-tailed) & .000 &. \\
\cline { 3 - 5 } & N & 301 & 301 \\
\hline
\end{tabular}

** Correlation is significant at the 0.01 level (2-tailed)

\section{Decision:}

From the $r=0.837$, the study outcome shows a high relationship between Software as a service (SaaS) and Accessibility. Further, based on the decision rule $p=0.00 \leq 0.01$. The null hypothesis stated is rejected and means a significant relationship between Software as a service (SaaS) and Accessibility.

$\mathrm{H}_{\mathrm{o} 2}$ : There is no significant relationship between Software as a service (SaaS) and records safety.

\begin{tabular}{|l|l|l|c|c|}
\hline \multicolumn{2}{|l|}{} & $\begin{array}{c}\text { Software as } \\
\text { a service }\end{array}$ & $\begin{array}{c}\text { record } \\
\text { safety }\end{array}$ \\
\hline \multirow{4}{*}{$\begin{array}{l}\text { Spearman's } \\
\text { rho }\end{array}$} & $\begin{array}{l}\text { Software as a } \\
\text { Service (SaaS) } \\
\text { and }\end{array}$ & $\begin{array}{l}\text { Correlation } \\
\text { Coefficient }\end{array}$ & 1.000 & $.866^{* *}$ \\
\cline { 3 - 5 } & Sig. (2-tailed) &. & .000 \\
\cline { 2 - 5 } & record safety & $\begin{array}{l}\text { Correlation } \\
\text { Coefficient }\end{array}$ & $.866^{* *}$ & 1.000 \\
\cline { 3 - 5 } & Sig. (2-tailed) & .000 &. \\
\cline { 2 - 5 } & $\mathrm{N}$ & 301 & 301 \\
\hline
\end{tabular}

**Correlation is significant at the 0.01 level (2-tailed).

\section{Decision:}

$\mathrm{H}_{\mathrm{o} 3}$ : There is no significant relationship between Platform as a service (PaaS) and records accessibility.

\begin{tabular}{|l|l|l|c|c|}
\hline \multicolumn{2}{|l}{} & \multicolumn{1}{|c|}{$\begin{array}{c}\text { Platform as } \\
\text { a service } \\
\text { (PaaS) }\end{array}$} & $\begin{array}{c}\text { Records } \\
\text { Accessibility }\end{array}$ \\
\hline \multirow{4}{*}{$\begin{array}{l}\text { Spearman's } \\
\text { rho }\end{array}$} & $\begin{array}{l}\text { Platform as a } \\
\text { service (PaaS) }\end{array}$ & $\begin{array}{l}\text { Correlation } \\
\text { Coefficient }\end{array}$ & 1.000 & $.900^{* *}$ \\
\cline { 3 - 5 } & Sig. (2-tailed) &. & .000 \\
\cline { 2 - 5 } & $\mathrm{N}$ & 301 & 301 \\
\cline { 2 - 5 } & $\begin{array}{l}\text { Records } \\
\text { Accessibility }\end{array}$ & $\begin{array}{l}\text { Correlation } \\
\text { Coefficient }\end{array}$ & $.900^{* *}$ & 1.000 \\
\cline { 3 - 5 } & Sig. (2-tailed) & .000 &. \\
\cline { 2 - 5 } & $\mathrm{N}$ & 301 & 301 \\
\hline
\end{tabular}

**Correlation is significant at the 0.01 level (2-tailed).
From the $r=0.866$, the study outcome shows that a high positive significant relationship exists between Software as a service (SaaS) and record safety. Further, the relationship shows significant at $p=0.00 \leq 0.01$. This implies that the null hypothesis stated is rejected and alternate hypothesis accepted that there exists significant relationship between Software as a service (SaaS) and record safety.

\section{Decision:}

From the $r=0.900$, the study outcome shows that a high positive significant relationship between Platform as a service (PaaS) and accessibility. Further, the relationship shows significant at $\mathrm{p}=0.00 \leq 0.01$. This simply means that the null hypothesis stated is rejected and means a significant relationship between Platform as a service (PaaS) and accessibilty.

$\mathrm{H}_{04}$ : There is no significant relationship between Platform as a Service (PaaS) and Record Safety.

\begin{tabular}{|l|l|l|c|c|}
\hline \multicolumn{2}{|l|}{} & $\begin{array}{c}\text { Platform as a } \\
\text { service } \\
\text { (PaaS) }\end{array}$ & $\begin{array}{c}\text { Record } \\
\text { Safety }\end{array}$ \\
\hline \multirow{4}{*}{$\begin{array}{l}\text { Spearman's } \\
\text { rho }\end{array}$} & \multirow{3}{*}{$\begin{array}{l}\text { Platform as a } \\
\text { service (PaaS) }\end{array}$} & $\begin{array}{l}\text { Correlation } \\
\text { Coefficient }\end{array}$ & 1.000 & $.900^{* *}$ \\
\cline { 3 - 5 } & Sig. (2-tailed) &. & .000 \\
\cline { 3 - 5 } & Records safety & $\begin{array}{l}\text { Correlation } \\
\text { Coefficient }\end{array}$ & $.900^{* *}$ & 1.000 \\
\cline { 3 - 6 } & Sig. (2-tailed) & .000 &. \\
\cline { 3 - 6 } & N & 301 & 301 \\
\hline
\end{tabular}

** Correlation is significant at the 0.01 level (2-tailed).

\section{Decision:}

From the $r=0.900$, the study outcome shows that a high positive significant relationship between Platform as a service (PaaS) and Records Safety. Further, the relationship shows significant at $p=0.00 \leq 0.01$. This simply means that the null hypothesis stated is rejected and means a significant relationship exist between the variables.

\section{FINDINGS}

From the findings, it was discovered that all variables of the predictor variable have high significant relationship with all measures of criterion variable with least correlation of $r=$ .837. This implies that leveraging on cloud computing certainly lead to records management efficiency. In other words. When there is increase practices of cloud computing in organization, there is tendency for higher record management efficiency in Niger Delta University.

\section{RECOMMENDATIONS}

Based on the findings the study recommends thus:

1. The Management of Niger Delta University should leverage on the available software service provider to store all students' records on cloud to avoid losses of records due to flood and other undue conditions.

2. Niger Delta University should engage cloud service providers with international standards practice repute for the purpose of records management efficiency. 
3. Cloud computing adoption in records management makes the organization efficient thereby panting good image of the institution and give it vantage competitive edge, hence, authorities of the school should utilize its model.

\section{REFERENCES}

[1] V C. Pinal (2012), Cloud computing in distributed system. International journal of engineering research \& technology, 1(10), 18.

[2] K.C Laudon, \& J. P Laudon, (2011), Management information system: managing the digital firm $12^{\text {th }}$ Edition. New Jersey: prentice hall.

[3] S. Bibi, D. Katsaros \& P. Bozanis, (2012), Business application acquisition: on-premise or saas-based solutions? IEEE Software 29(3):86-93.

[4] R. Buyya, C.S Yeo, S. Venugopal, .J. Broberg and I. Brandic (2009), Cloud computing and emerging it platforms: type and reality for delivering computing as the $5^{\text {th }}$ utility; Future generation computer systems $(25) 6,599-616$.

[5] B. Wheeler, and S. Waggenor (2009). Above campus service: shaping the promise of cloud computing for higher education. Educause review, (44(6), 52.

[6] M. P. Peter and G. Timothy (2011), The NIST Definition of Cloud Computing, recommendations of the National Institute of Standards and Technology.

[7] M. Langemo, (1994). Awareness and use of electronic records management for administrative effectiveness. Retrieved https://www.studocu.com/row/document/american-university-ofnigeria/advanced-management-theory-practice/other/awareness-anduse-of-electronic-records-management-for-administrativeeffectiveness/7076730/view 24/08/2020.

[8] N. K. Malhotra, (2004). Marketing research: An applied orientation, $4^{\text {th }}$ Edition. Pearson Education Inc.

[9] United Nations Archives and Records Management Section (nd), Retrrieved; https://archives.un.org/sites/archives.un.org/files/8guidance_protecting_records_from_loss.pdf 20th/08/2020.

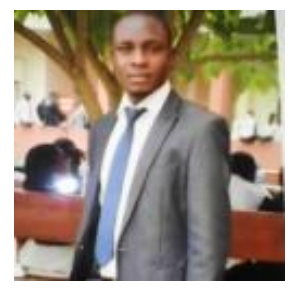

Amakiri Don-Solomon hails from Akakumama comummunity in Nembe LGA of Bayelsa State, Nigeria. He was born in 17 th Dec. 1987. He holds B.sc degree in Office Management Technology in Niger Delta University 2010. M.sc in Management from University of PortHarcourt 2015. And currently a Ph.D scholar of Organizational Behavior in Niger Delta University. He currently lectures in the Department of Office and Information Management, Faculty of Management Sciences, Niger Delta University Wilberforce Island, Bayelsa. He has authored 17 articles in peer reviewed local and international journals, 2 books - Christian literatures and anchored several online facilitation and programs. $\mathrm{He}$ is a motivator, infopreneur, teacher, prolific writer, researcher and Christian, married to selina with two kids. 